\title{
The construction of an elusive concept: Framing the controversial role and practice of lobbying in Swedish media
}

Public Relations Inquiry 2017, Vol. 6(3) 275-29I

(C) The Author(s) 2017

Reprints and permissions: sagepub.co.uk/journalsPermissions.nav DOI: 10.1 |77/2046147XI77|3543 journals.sagepub.com/home/pri

@SAGE

\section{Elin Helgesson and Kajsa Falasca}

Mid Sweden University, Sweden

\begin{abstract}
This study seeks to explore the relation between the elusive scholarly concept and the media framing of the role and practice of lobbying. The longitudinal study analyses a time period of 10 years in Sweden when lobbying has taken on an increasingly influential role in the political system. The results, based on a content analysis of news articles and opinion editorials in five national newspapers and trade media, illustrate that the perception of lobbying is without nuance and a common negative frame is present and continues to be reproduced. Furthermore, a clear contradiction is evident in the relation between the scholarly debate and the mediated debate of the practice. The article discusses what this setting and inconsistency implies for current society and democracy, and the citizen trust in political representatives and institutions.
\end{abstract}

\section{Keywords}

Content analysis, framing, lobbying, public affairs

\section{Introduction}

The role and practice of lobbying in modern democratic societies is in many cases a controversial subject (Baumgartner et al., 2009; Coombs and Holladay, 2013; Davidson and Rowe, 2016; Ihlen and Berntzen, 2007; Mahoney, 2008; Moloney, 2002; Naurin, 2007b). Lobbying as the influence of organized interests on the political policy process is not a new practice (Milbrath, 1963), and the right to influence is generally fortified in

\footnotetext{
Corresponding author:

Kajsa Falasca, Department of Media and Communication Science, Mid Sweden University, Holmgatan I0,

85I 70 Sundsvall, Sweden.

Email: kajsa.falasca@miun.se
} 
democratic constitutions. Yet, the essence and impact of lobbying are questions that are subject to extensive scholarly discussion. Besides exploring lobbying as significant part of an effective democracy, many scholars highlight the complexities that accompany this concept, stressing issues of inequality, ethics, and accountability in relation to the practice (Boddewyn, 2012; Davidson and Rowe, 2016; Fleisher, 2012; Hill and Varone, 2014; Schwarzmantel, 1994). Some scholars even discuss that lobbying can be regarded as a form of legal corruption since it is a form of influence induced by the private sector on governments for preferential treatment (Campos and Giovannoni, 2007; Esteban and Ray, 2006; Kaufmann and Vicente, 2011).

The influential and prominent function of lobbying in the political process has recently gained attention among researchers in Sweden (Garsten et al., 2015; Strömbäck, 2011; Svallfors, 2016a). Swedish politics are in a process of transformation, moving from corporatism toward a more pluralistic character. Changing political prerequisites have opened up new ways and channels to exert political influence, creating the foundation for a unique lobbying arena (Hall, 2015; Larsson, 2006; Naurin, 2007a). With more sophisticated and professionalized methods and strategies, lobbying has moved into a new era, and public relations (PR) agencies 'are now key players in the political landscape' (Svallfors, 2016b: 508). At the same time, there is a clear absence of recognition of lobbying as a legitimate practice in society. Studies have found that governmental and parliamentary contact with lobbyists was seen as an alien intrusion that does not belong in political life by the Swedish public, and only one-tenth of the population express that they find lobbyists trustworthy (Larsson, 2007, 2009). The public perception can be highly affected by media reporting. News framing of an issue can have an impact on public opinion since the media are the most important source for citizens in terms of political information (De Vreese, 2014; Entman, 2004; Strömbäck and Nord, 2008). In other words, news and opinions presented in a mediated debate on the subject of lobbying are of importance for the public's understanding of lobbying and its role in the political landscape.

Against this background, the purpose of this article is to explore the relationship between the elusive scholarly concept of lobbying and the media framing of the role and practice of lobbying. In this article, Sweden is used as an example of a political system where lobbying has taken on an increasingly influential role and has become more common in the political process in the past decade (Hall, 2015; Svallfors, 2016b). The article explores the ways in which lobbying and lobbyists are defined, described, and framed in Swedish media from 2006 to 2016 through a content analysis of articles and opinion editorials (op-eds) in five national newspapers and trade media. A longitudinal research design allows this article to explore media framing over time (Bennett and Elman, 2006) as the role and practice of lobbying transforms. In doing so, the article contributes with insights on the media portrayal of lobbying that may affect citizens' understanding, views, and trust in political representatives and institutions.

\section{Lobbying - An elusive concept under debate}

Part of the controversy surrounding the concept of lobbying is rooted in the perception of lobbying as something good or bad, or as Ihlen and Van Ruler (2009) argue concerning PR, 'it is in itself not good or bad, but it can be used for good or bad causes' (p. 5; 
Dühring, 2015). This perception of lobbying as either 'democratic influence' or 'legal corruption' highlights questions surrounding the role and practice of lobbying dealing with issues of power, accountability, and inequality of different interests in society (Davidson and Rowe, 2016).

The core of lobbying is perceived as straightforward - it is a process by which organized interests through strategic communication seek to influence the political policy process (Davidson, 2015; Milbrath, 1963; Somerville, 2011). Yet, despite the obvious core traits of lobbying, it has proved notoriously difficult to define. The debate began more than 50 years ago when Milbrath (1963) summed up the current lobbying research and stated that "the words "lobbyist" and "lobbying" have meanings so varied that use of them almost inevitable leads to misunderstanding' (Milbrath, 1963: 7). Furthermore, the concept of lobbying has an interdisciplinary nature and draws on insights from different fields such as political science, public affairs, and communication which might be an underlying cause to the hybrid definitions (Dühring, 2015; Edwards, 2012).

The ambiguity of lobbying as a concept can moreover be related to the shape shifting form of lobbying, and many scholars emphasize that lobbying has dynamic qualities since it is context dependent (Eising, 2007; Lowery, 2007; Nownes, 2006). Nownes (2006) sums it up by stating that 'lobbying is a complex and heterogeneous phenomenon' (p. 2), since it takes place at several levels of government, using different techniques and strategies; it is performed by a wide variety of organizations that promote an even wider variety of issues. Furthermore, the political setting and institutional structure influence how the lobbying processes transpire and what techniques are suitable (Badie et al., 2010; Nownes and DeAlejandro, 2009). This suggests that lobbyists have to alter and adapt how they work according to the current context, as the political setting and preconditions never look absolutely the same neither over time, nor if two separate political systems are compared.

A dividing point among researchers comes down to a discussion of what methods and strategies should be regarded as lobbying. While some only regard direct contact as lobbying, others include formation of opinion, media contacts, and other indirect methods and thus promote a more extensive definition (Ihlen and Berntzen, 2007; Strömbäck, 2011). Traditionally, Swedish research has distinguished lobbying from the formation of opinion; however, more contemporary research combines the two to a greater extent. The cohesive structure of political parties and interest organizations in Sweden makes indirect lobbying methods highly relevant and more commonly used in comparison with many other countries (Garsten et al., 2015; Tallberg et al., 2011). Therefore, these scholars argue that a narrow definition is inadequate to capture the many facets of Swedish lobbying since a significant part of the lobbying industry consists of indirect lobbying strategies and efforts.

\section{Framing as a process of describing and defining}

How media describe, define, and frame the role and practice of lobbying can have considerable impact on the general understanding and societal validation of lobbying. It has for long been agreed that interactions with news media influence citizens when it comes to political learning, opinion, and behaviors since media are a significant agent and central source of political information (Bennett and Entman, 2001; Esser and Strömbäck, 2014). 
In general terms, framing is anchored in the perception that the construction of a message and the elements chosen to portray an issue, a person, action, or event influence the receiver's understanding of it (Entman, 2004; Scheufele and Tewksbury, 2007; Shah et al., 2009). By making some aspects more salient, a certain interpretation is promoted. Apart from influencing the understanding and assessment on an individual level, frames may also influence on a societal level that includes processes such as decision-making, political beliefs, and opinions. Hence, framing is a dynamic process - a message exchange - rather than a static component. The framing process occurs in two steps: (1) frame-building, where a frame is constructed and (2) frame-setting, the interaction between the presented media frame and the receiver's knowledge (De Vreese, 2005). The second part of the process - the frame-setting - has received the most attention as the majority of research has focused on framing effects, leaving the research on how a frame emerges overshadowed (De Vreese, 2005; Scheufele and Tewksbury, 2007).

One perspective on frame-building highlights a connection with culture, emphasizing that frames exist beyond an individual level, as they are anchored in a shared cultural context (Shah et al., 2009). Cultural aspects such as organized sets of beliefs, values, and norms influence how a frame is constructed. This naturally does not mean that only one frame of an issue can occur, rather the contrary, but it implies that there are certain kinds of frames of an issue that are more likely to occur. The cultural setting can set a foundation in the framebuilding process even though a frame is essentially created in the interaction of several actors. The interplay between different actors, such as journalists and their sources or opinion editors and lobby practitioners, results in a certain frame where some qualities are more salient than others, including features such as words, examples, arguments, metaphors, and images. Entman (2004) sums it up by stating that this process entails (1) defining effects or conditions as problematic, (2) identifying causes, (3) conveying a moral judgment of those involved in the framed matter, and (4) endorsing remedies or improvements to the problematic situation. Since media frames are dynamic and created through the interplay between actors, they can change over time. New frames are selected and constructed, other ones may disappear, whereas some frames linger and continue to be reproduced. A certain frame can become dominant making other frames of the same issue irrelevant, while various frames surround some issues at the same time (Entman, 2004; Shah et al., 2009). The media framing of the role and practice of lobbying in Sweden during a time period when the political policy process transformed is an interesting example to study since it can tell us about the interplay between a scholarly discussion and a mediated discussion concerning lobbying.

\section{The role and practice of lobbying in Sweden}

A specific historical and political culture has formed the current Swedish political policy process that makes Sweden stand out internationally as a lobbying arena. There are two central characteristics that have made Sweden rather unique. First, Sweden has experienced a high extent of formal influence by organized interests, a trademark that was instituted in the 'Swedish model' developed in the 1930s. To level out power imbalances, the state delegated parts of its decision power to labor market organizations and trade unions, and thus gave these stakeholders a unique position of political influence in an institutionalized form. However, the emphasis of this sort of formal influence rapidly 
disappeared in the 1990s when organizations withdrew from the model in favor of less center-oriented participation (Hall, 2015). Second, commissions of inquiry and a referral system have been central to the policy-making process. Political decision-making in Sweden has thus involved several types of actors. Political issues are investigated by a commission of inquiry, involving public agencies and relevant interest groups for comments in a referral system, before parliamentary decisions are made (Petersson, 2015). However, during the last decade, fewer inquiries are conducted and they have been ordered to finish their assignments in less time and deliver shorter reports.

Deliberation and dialog through community organizations have thus been an integral part of Swedish politics to keep the public informed of and participating in the political policy process (Falasca and Nord, 2013). However, the political policy process has moved from consensus seeking based on privileged access for selected organized interests to a more competitive system. This has opened up for an increasing number and variety of organized interests to participate and compete in a more 'market-oriented' fashion in the policy process, as well as creating a setting for lobbyists to exert political pressure in a more informal manner (Hall, 2015; Larsson, 2006; Petersson, 2015). The number of organizations who lobby is constantly increasing, and studies show that the majority of Sweden's 500 largest organizations do some sort of lobbying activity (Garsten et al., 2015; Nothhaft, 2011). At the same time, agencies that lobby have moved into the political policy process as new key players (Svallfors, 2016b). However, lobbying is regarded with suspicion and perceived as an illegitimate practice by the Swedish population (Larsson, 2007, 2009). In the political sphere, several inquiries have been ordered on lobbying to investigate what this form of influence on politics entails in a Swedish context. The latest inquiry was launched in March 2016 to examine a possible conflict of interest as individuals transfer between employment in government, politics, and lobbying. However, no official decision regarding regulation or registration of the lobbying industry in Sweden has yet been made.

In essence, lobbying is an attempt by organized interests to influence the political policy process through strategic communication. This form of influence has a long history in Sweden, but the role and practice of lobbying has changed over time. However, in spite of a growing presence in the political sphere, lobbying lacks societal validation and is regarded by the public as an illegitimate practice. Since media content is a central source of information, news and a mediated debate concerning the role and practice of lobbying are of importance for the public understanding of lobbying. Therefore, this article aims to explore how lobbying is defined, described, and framed in the Swedish media. It is a long-term study of the media coverage of lobbying in news and trade media during a 10-year period when the lobbying industry expanded. The purpose of the article leads to the following research questions:

RQ1a. How did Swedish news and trade media frame the role and practice of lobbying during the time period 2006-2016?

$R Q 1 b$. Did the framing of the role and practice of lobbying change during the time period 2006-2016?

$R Q 2$. What themes and issues of lobbying are discussed in Swedish news and trade media? 
Table I. Sample.

\begin{tabular}{llccr}
\hline Journal & Description & $\begin{array}{l}\text { Total number } \\
\text { of texts }\end{array}$ & $\begin{array}{l}\text { News } \\
\text { articles }\end{array}$ & Op-eds \\
\hline Aftonbladet & Leading daily tabloid & 113 & 69 & 44 \\
Dagens Nyheter & Leading daily morning paper & 103 & 71 & 32 \\
Dagens Samhälle & Political trade media & 37 & 35 & 2 \\
Dagens Media & Public relations trade media & 21 & 20 & 1 \\
Resumé & Public relations trade media & 126 & 120 & 6 \\
N & & 400 & 315 & 85 \\
\hline
\end{tabular}

\section{Method and data}

To answer the research questions posed, focusing on how lobbying and lobbyists are defined, described, and framed in Swedish media over time, this study employs a longitudinal research design. The selected time period is from the election year of 2006 and a decade forward up to 2016, an especially interesting time period during which lobbying became more common and the role of lobbying became more influential in the political sphere in Sweden. By designing a longitudinal study, we can compare media framing of lobbying and investigate the development over time (George and Bennett, 2005). The study is based on a quantitative content analysis of Swedish news and trade media, using the same code schema ensuring systematic comparability (Riff et al., 2014). The media outlets were strategically chosen to represent a variety of news media and trade media. The sample consists of two of Sweden's largest newspapers, one being a daily tabloid Aftonbladet and one a daily quality newspaper Dagens Nyheter, both with national reach and coverage. The remaining three outlets are trade media, two aimed at a national audience of PR and media professionals Resumé and Dagens Media and one aimed toward political policy makers and the public sector, Dagens Samhälle.

The unit of analysis was full news stories and op-eds in the form of debate articles and columns, which is the most widely used methodology and approach in research on news content (Esser et al., 2012). Texts shorter than five lines, different lists, as well as reviews were thus not included in the sample. The articles had to make reference to lobbying, lobbyists, public affairs, or the role of lobbying in the political sphere to be selected. In total, the sample consisted of 400 articles and op-eds (Table 1).

\section{Measurements}

A code sheet was developed specifically for this study to include several relevant questions such as topics and frames that constitute the media image of lobbying and its relation with democracy. Every article and op-ed was analyzed for the dominant tone when defining, describing, or framing lobbying; a positive, negative, neutral, or mixed tone. Specific words, expressions, and terminology depicting lobbying as either negative or positive were used to determine the overall tone. Comments such as 'lobbying ensures that more voices are heard in the political debate' were ascribed as positive, whereas 'lobbying has damaging effects on democratic processes' were ascribed as negative. 
Articles and op-eds containing both negative and positive terminology were coded as mixed and those with neither positive or negative comments were coded as neutral. The coder was thus asked to determine the dominant tone in each unit of analysis. News articles and op-eds were also analyzed regarding whether they contained speculations concerning the effects of lobbying on the democratic system. This variable was designed to capture the extent to which the media frame lobbying as a negative phenomenon in society. Articles or op-eds presenting speculations or arguments concerning negative effects of lobbying on the democratic system were coded as negative. Furthermore, the code sheet included 16 variables to identify which specific topics related to lobbying were central in the articles and op-eds. These were topics such as minister quarantine, 'revolving doors' between employment in government, politics and lobbying, conflict of interest, transparency, and so on. The coder was asked to identify whether any of the 16 topics were present in the articles. Finally, a number of different source categories were defined and included in the content analysis. A source was coded as present when defined as an individual with a directly attributed quote, statement, or fact in the articles and opeds. The categories used were as follows: politicians, PR or public affairs professionals, experts such as social science researchers, and citizens.

One trained coder conducted the coding and finally, an intracoder test was conducted by recoding 10 percent $(n=40)$ of all the articles and op-eds. The result of the test showed an overall reliability of 97.6 percent for the 39 variables used in the analysis.

\section{Results}

As presented earlier, the lobbying industry in Sweden is prospering, with a growing number of lobbyists, lobbying firms, and organizations involved in the political policy process (Garsten et al., 2015; Nothhaft, 2011; Svallfors, 2016b). The growing presence of lobbying has not gone undetected by the Swedish media. The results illustrate that the total number of articles on the role and practice of lobbying has increased steadily over the 10 -year period of the study. The increase in articles on lobbying over time could signify that the topic is perceived as more interesting and newsworthy (Reinemann et al., 2012). The peak in 2013 can be traced to a special series focusing on the lobbying industry conducted by Aftonbladet. Of the total number of articles during 2013, Aftonbladet published 38 of the total 70, an occurrence that should be taken into consideration when looking at the results and tables. Another interesting divergence in the progression pattern emerges when analyzing each journal individually. In spite of an overall increase, some of the journals demonstrate a decrease in the number of articles. Starting in 2012, two of the papers, Aftonbladet and Resumé, had an increase in articles in comparison with the previous years, a development that is not reflected in the remaining three journals. Apart from a high increase in the number of articles published in Dagens Nyheter during 2015, the three papers Dagens Nyheter, Dagens Media, and Dagens Samhälle reporting on lobbying remain around the same level as before, or are decreasing since 2012. This deviation between papers shows a contradictory development on the reporting of lobbying, a deviation that differs between both the different newspapers and the different trade media. Thus, the results indicate that different media appear to vary in their news evaluation, in other words what they deem newsworthy topics. This is also 
Table 2. Distribution between news articles and op-eds over time (\%).

\begin{tabular}{lrrrrrrrrrr}
\hline & 2006 & 2007 & 2008 & 2009 & 2010 & 2011 & 2012 & 2013 & 2014 & 2015 \\
\hline News articles & 95 & 79.3 & 84 & 84.4 & 86.8 & 75 & 68.2 & 77.1 & 81.3 & 72.4 \\
Op-eds & 5 & 20.5 & 16 & 15.6 & 13.2 & 25 & 31.8 & 22.9 & 18.7 & 27.6 \\
Total & 100 & 100 & 100 & 100 & 100 & 100 & 100 & 100 & 100 & 100 \\
$\mathrm{n}$ & 20 & 29 & 25 & 32 & 38 & 36 & 44 & 70 & 48 & 58 \\
\hline
\end{tabular}

$N=400$.

highly connected to the fact that different media operate with different media logic. Previous research indicates that tabloid formats (as Aftonbladet) to a larger extent focus on 'soft news' in comparison with broadsheet news (Reinemann et al., 2012). This entails a news evaluation with a stronger focus on sensationalism, personality-centered, and incident-based news. The indication that Aftonbladet as a tabloid and Resumé which appears to focus on soft news as well have increased its coverage of lobbying could hence be argued to be a sign of similarity in their news evaluation. Moreover, it may be reasoned that the controversial aspect of lobbying makes it suitable and easily transformed into soft news as it stirs ups strong emotions, which could be an underlying factor for the intensified focus on lobbying in these outlets.

Another trend that could be argued to highlight a growing interest in lobbying is that the number of op-eds has increased. As with the overall reporting, the largest fluctuation in number of op-eds occurs after 2011, when the total number of op-eds almost doubled in volume. However, this increase is almost exclusively seen in the news media, whereas the number of op-eds in trade media remains low. That the topic of lobbying is selected for op-ed format besides regular news reporting indicates that the discussion and public debate on lobbying has become more intense. Whereas the low number of op-eds in trade media could be an indication that the subject is not regarded as either controversial or an interesting subject for debate within the industry (Table 2).

\section{A critical approach}

When analyzing the content, a trend emerges when it comes to the overall tone in the reporting. A majority of articles have a negative outlook when describing and debating lobbying, an inclination that is visible throughout the entire material. Approximately half of the articles over a majority of years have a negative stance on lobbying (Table 3).

That such a clear negative image is present and that it is persistent over time indicates that a media frame exists, and that it continues to be reproduced over time. As frames arise from a cultural understanding, it is possible that the strong emphasis on the negative stance has grown out of Sweden's long history of formal and institutionalized influence, making the concept of lobbying seem alien (Entman, 2004). Hence, the distrust toward lobbying might be a result of the Swedish culture influencing media choice of frames. Furthermore, it can be argued that the societal negative understanding and media portrayal are amplifying each other, where media pick up the societal concern of lobbying, reproduce it, and in doing so ratify the negative description. 
Table 3. Overall framing of lobbying (\%).

\begin{tabular}{lcccccccccr}
\hline & 2006 & 2007 & 2008 & 2009 & 2010 & 2011 & 2012 & 2013 & 2014 & 2015 \\
\hline Positive & 15 & 6.9 & 16 & 15.6 & 15.8 & 8.3 & 11.4 & 12.9 & 12.5 & 3.6 \\
Negative & 55 & 41.4 & 32 & 50 & 60.5 & 50 & 41 & 58.5 & 39.6 & 56.9 \\
Neutral & 30 & 44.8 & 44 & 25 & 18.4 & 25 & 43 & 15.7 & 33.3 & 24.1 \\
Mixed & - & 6.9 & 8 & 9.4 & 5.3 & 16.7 & 4.6 & 12.9 & 14.6 & 15.5 \\
Total & 100 & 100 & 100 & 100 & 100 & 100 & 100 & 100 & 100 & 100 \\
$\mathrm{n}$ & 20 & 29 & 25 & 32 & 38 & 36 & 44 & 70 & 48 & 58 \\
\hline
\end{tabular}

$N=400$.

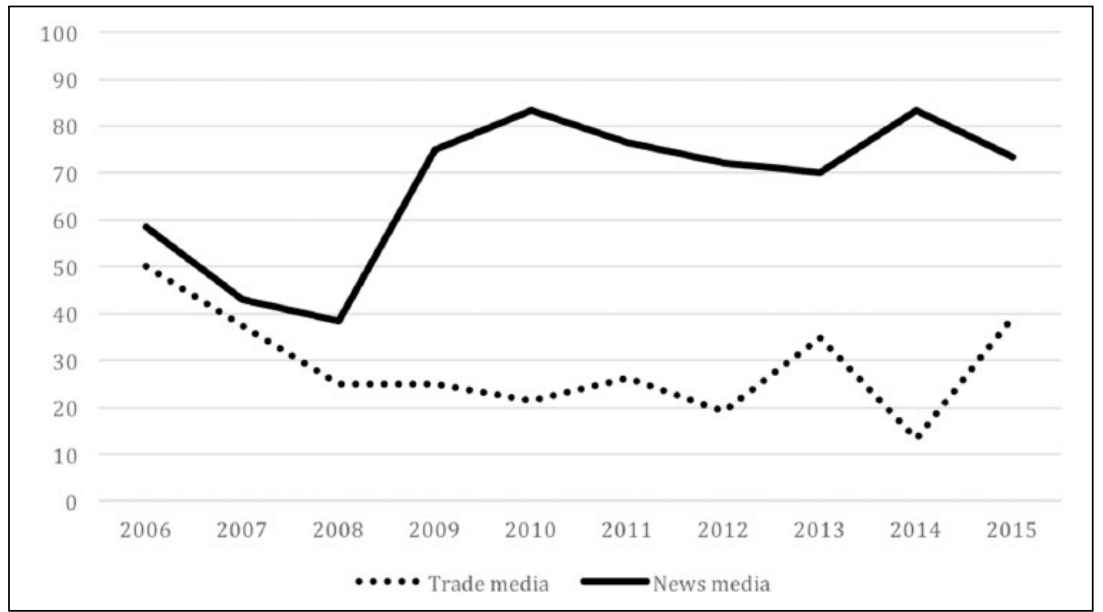

Figure I. Overall negative framing (\%). $N=400$.

However, there is a clear divergence when comparing the results between trade media and news media. The results illustrate that trade media are less negative in reporting in comparison to newspapers. The negative framing in trade media is most significant in 2006 when it peaks at 50 percent of the articles published that year, followed by a decline. In comparison, the fluctuation seen in the news media framing illustrates a heavy increase in texts with negative framing of lobbying. From 2010 and forward, the percentage of negative articles publish each year remains more than 70 percent in the news media outlets, peaking at a total of 83 percent in 2010 and 2014 (Figure 1).

The result clearly displays the news media's tendency to frame the role and practice of lobbying as something negative, a result that in a similar fashion may be related to the different criteria in their news evaluation and altering media logic connected to different media formats as discussed earlier. Therefore, it can be argued that trade media convey a more nuanced image of lobbying and its role in politics, due to its aim and scope. 


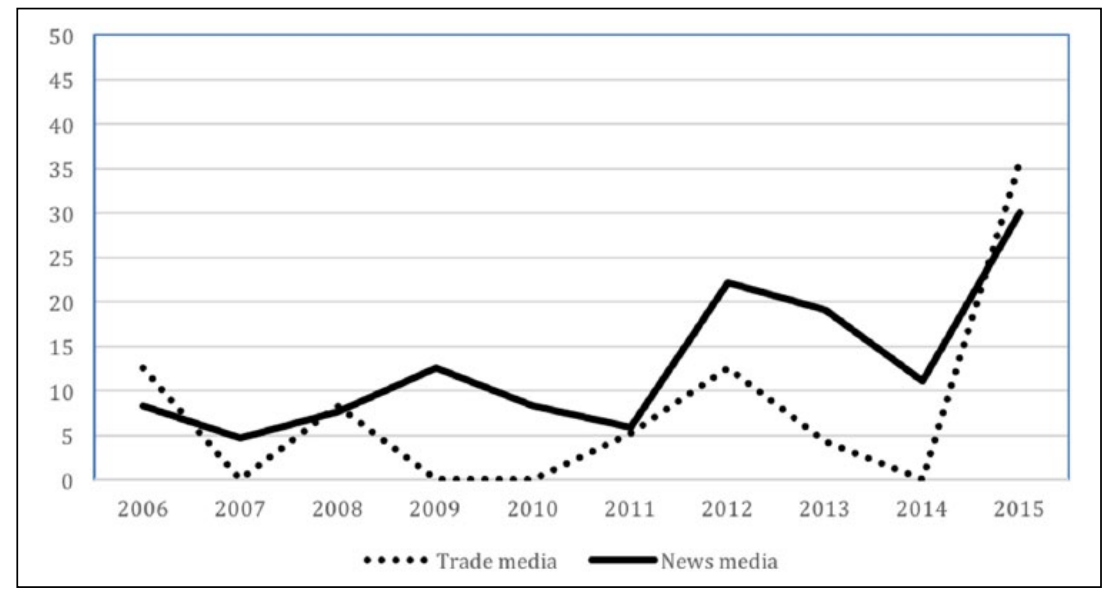

Figure 2. Articles containing speculations of lobbying's negative effect on democracy (\%). $N=400$.

\section{A growing concern}

The negative associations the Swedish population hold when it comes to lobbying are also an aspect that is reflected in the media framing (Larsson, 2007, 2009). However, an interesting change has occurred in how the negative side of lobbying is manifested. A trend that occurs is that there appears to be a growing concern for how lobbying impacts on democracy. The same goes for speculation on the potential negative impact of lobbying on the Swedish policy process. The number of articles that speculate on negative effects of lobbying rise drastically over time starting during 2011, and in 2015 no less than a third of the total number of articles and op-eds highlight the potential risks and negative effects lobbying may have on Swedish democracy. As with the overall negative framing, news media address this issue to a higher extent than trade media, and an overall increase can be seen in the later part of the studied timespan. A peak occurs in the trade media outlets in 2014; this peak might be connected to a scandal in 2014 when a famous former politician transferred to a position as a lobbyist. The change of position gave new fire to a heated debate that resulted in the political decision that launched a governmental inquiry focusing on the so-called 'revolving door', where politicians change from the position of being subjects to lobbying into positions in the industry as lobbyists and sometimes back again into the position as elected politician (Figure 2).

The results thus show that both news and trade media discuss the potential negative impact of lobbying on democracy. Especially news media seem to pursue a frame where lobbying is regarded as a negative development of the political process. Whereas trade media acknowledge the potential risks connected to lobbying, but are also more willing to approach the subject from different angles.

\section{The lobbyist in the center}

Apart from a change in focus regarding the negative portrayal of lobbying, the overall aspects of lobbying that are debated have shifted over time. An interesting aspect when 


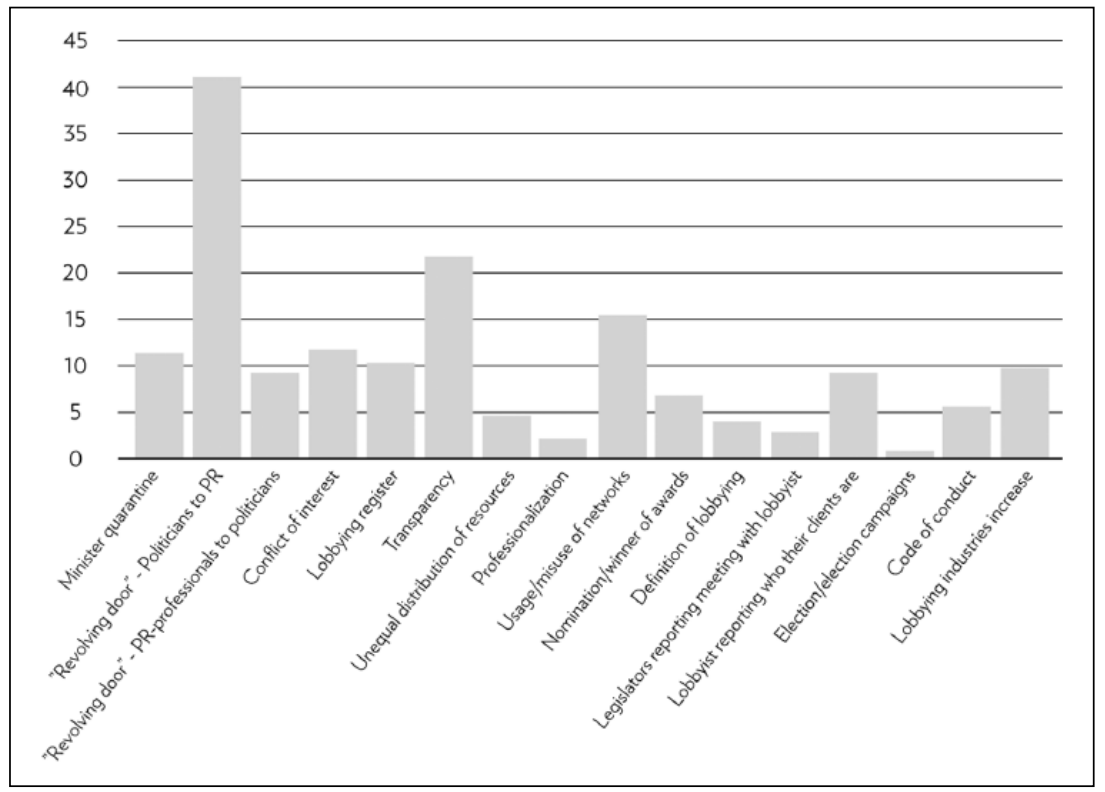

Figure 3. Topics (\%). $N=400$.

analyzing the development is that no topic has 'disappeared' over time. A closer look even illustrates that no topic has seen any great decrease in coverage over the years. Instead, the main changes are related to clearly increased reporting of certain subjects.

A topic that stands out in terms of frequency concerns the before-mentioned 'revolving door', a term given to the transfer between employment in government, politics, and lobbying. The revolving door is a complicated matter in Sweden, something that most likely is an underlying factor for the strong emphasis on the topic. The historical setting with once formal institutionalized participation of specific organized interests has created a very complex political system where the balance between policy advice and policy advocacy is very vague (Petersson, 2015). In addition, it should be considered that Sweden being a small nation by international comparison has a small political sphere consisting of closely intertwined networks of people. This context has made transfers between the two spheres of politics and lobbying highly questioned as it raises questions of confusion of roles and conflicts of interest. The centrality of the issue is furthermore evident in the choice by the government to launch an inquiry on the subject during 2016 (Figure 3).

Former politicians transferring to a job in PR is the topic most written about, appearing in 41 percent of the total number of 400 articles. The subject has been debated over the entire 10-year period, but an increase is visible over time, illustrating that it is a topic that has gained more attention. Certain peaks occur at times when notable Swedish politicians change their career, as when former (1996-2006) Prime Minister Göran Persson took a position as a lobbyist at the influential firm JKL in 2007, or the famous healthcare politician Filippa Reinfeldt's change of position in 2014. 
In a similar fashion, minister quarantine (11.2\%) and conflict of interests $(11.7 \%)$ are two topics that are highly intertwined with the revolving door issue and are commonly occurring themes in the media. Furthermore, a topic that receives a great deal of attention in the media coverage is the usage/misusage of personal networks of contacts $(15.2 \%)$. However, besides illustrating which issues are seen as the most central in the media, all these topics to a large extent favor a definition of lobbying as direct contact between politicians and lobbyists. The strong fear that politicians will misuse the closely related roles, their knowledge and their networks and transfer to a profession as advocates, focuses on aspects of lobbying that are closely linked to the individuals performing the practice, in other words the lobbyists. Based on this, it could be argued that the complexity of lobbying is not captured in media coverage. This also indicates the existence of a media frame, which continues to be reproduced despite scholars arguing that this form of definition is lacking nuance (Garsten et al., 2015; Strömbäck, 2011; Tallberg et al., 2011).

This line of thought could also be an underlying factor to the common negative approach to lobbying found in news media. The dilemma is related to the understanding that there are two ways to approach lobbying as a concept, either by an agency approach focusing on the individual 'the lobbyist' or by a structure approach emphasizing the context and thereby 'lobbying' as a phenomenon. One problematic aspect of the actororiented perspective is that the restricted way of viewing lobbying would imply that only individuals hired to lobby, for example, consultants, perform actual lobbying. Accordingly, activities performed to influence the policy process done by, for example, organizations and trade unions, would not be regarded as lobbying efforts. An understanding of lobbying as something that requires a professional lobbyist would hence imply that not all actors in society have the same opportunity to influence if access to politicians and recourses to hire professionals are seen as necessary elements. This perspective would hence diminish a public discussion concerning the democratic values of lobbying.

Another result that reinforces the strong focus on the individuals in the lobbying interaction can be found when looking at which news sources are the most common. The results illustrate that there are two categories of sources that are used more than others. That is the groups consisting of politicians (occurring in $23.3 \%$ of the texts) and PR and public affairs professionals (occurring in 28.8\%). In comparison, experts such as social scientist researchers, who are bound to be more objective than other groups, are only asked to comment in 7.5 percent of the texts. The category that is the least common as a news source is citizens $(1.3 \%)$, an interesting result since the role and practice of lobbying is not regarded by the public as legitimate or belonging in a democratic system. In other words, even though citizens seem to have strong opinions concerning lobbying, their voices are very seldom heard in the media coverage on lobbying.

\section{Discussion and conclusion}

This study departed with the aim of exploring the relationship between the elusive scholarly concept of lobbying and the ways in which lobbying is defined, described, and framed in Swedish media. The article thus reviews how a crucial societal issue is presented to citizens and which themes of this multifaceted topic are highlighted in the 
media debate. The study is longitudinal to see whether and if so media coverage on the role and practice of lobbying has developed over time as the political landscape in Sweden has transformed. A content analysis of 400 news articles and op-eds from two leading newspapers and three trade media illustrates that lobbying is a subject that has not slipped under the radar. The results of the study highlight three main themes and contradictions in the media coverage.

First, the analysis illustrates that media coverage on lobbying has increased over time and that the debate has intensified. However, the growing number of articles does not mean that a more nuanced depiction of lobbying is presented in the media. On the contrary, the results indicate that there is an established negative news frame of lobbying. A substantial share of the media content (mean value $49 \%$ of all content) uses a negative tone when defining, describing, or framing lobbying and it is evident that media are more keen to see the risk with lobbying rather than the benefits. The negative portrayal is noticeable in all media outlets, even though it is especially noticeable in the news media outlets, and is persistent over time indicating that a common negative frame is present and continues to be reproduced. Whether or not this negative news frame is anchored in changing media logic and news evaluation is a question that requires further research (Reinemann et al., 2012; Shah et al., 2009). However, the strong emphasis on the negative characteristics of lobbying over time in media coverage can give the audience a very one-sided image of lobbying. It may also have important implications for the professionalization process of lobbying as an occupation as it tries to gain occupational legitimacy and social validation (Garsten et al., 2015). There has also been a significant increase in op-eds debating lobbying in Swedish news media. The publication of more and more op-eds over time is an indication of an intensified debate and that lobbying is an issue of importance in the social debate. All in all, there is a clear contradiction between the scholarly discussions and the media coverage in terms of lobbying as a negative or positive political phenomenon since the media are mainly negative and rarely discuss lobbying from other viewpoints (Davidson and Rowe, 2016). The trade media, even though a fair share of negative framing is visible in these outlets as well, appear more open to discuss lobbying from different angles. Trade media coverage of lobbying thus seems to be less sensational and more nuanced. This result is not surprising since trade media are directed at practitioners in the industry and therefore can address the issue from an insider perspective.

Second, the reporting on lobbying has a strong focus on the individuals in the lobbying process, in other words the politicians and the lobbyists. This emphasis is not only noticeable in the selection of topics such as the revolving door, conflict of interest, and minister quarantine. An interesting point is how this focus influences the overall definition of lobbying. The vigorous focus on individuals and the actual meeting can in itself have implications for citizens' understanding of lobbying as it sets up a very narrow perspective on the role and practice of lobbying. This indicates that Swedish media prefer to define lobbying according to a less extensive fashion focusing on only a slim facet of the total amount of lobbying efforts (Garsten et al., 2015). This highlights another contradiction between the scholarly definition and media portrayal of lobbying, where the media use a narrow definition in comparison to scholars who at large promote a more extensive definition (Ihlen and Berntzen, 2007). Swedish scholars are trying to widen the 
definition of lobbying in Sweden, as the structure of the Swedish political system makes a narrow definition inadequate to capture all the facets of Swedish lobbying. Hence, scholars are trying to draw attention toward the methods and context of lobbying, rather than the participating individuals (Svallfors, 2016b). An important aspect to bear in mind is that a narrow definition of lobbying with a focus on the individual lobbyist creates a setting where only professional lobbyists are regarded as lobbying. This narrow definition would, for example, exclude organizations and trade unions even though they 'technically lobby'. Furthermore, the emphasis on direct lobbying may result in an increasingly one-sided debate on lobbying where indirect methods and efforts are rarely examined, a situation that would be intricate since indirect lobbying is the main form of lobbying in Sweden (Svallfors, 2016b).

The one-sided definition of the role and practice of lobbying in media coverage compared to the hybrid research definitions could furthermore diminish the perception of lobbying as a democratic cornerstone. This brings us to the third main result of the study - that lobbying is often characterized as a potential hazard. Adding to the general negative framing, a common theme in the material is a great concern about the risks lobbying pose to democracy. The understanding of lobbying as an 'elite profession' that is performed by lobby professionals removes the democratic values of lobbying as an opportunity for all interests to influence public political processes (Hill and Varone, 2014). Hence, the present media image of the role and practice of lobbying could strengthen distrust toward lobbyists, increase the gap between citizens and the political process, remove lobbying from being viewed as democratic, and thereby potentially weaken a core element of the democratic system. Nevertheless, organized politics has transformed in Sweden and lobbying plays an important part in the political policy process, moving power from corporatism involving interest organizations and trade unions, toward corporatists and agencies that lobby (Svallfors, 2016b). This powershift is described as an alarming political change in the media coverage. The changing role and practice of lobbying is seen as revolutionary rather than evolutionary, and as a change that has occurred rapidly rather than something that has evolved as the political system changes. Again, this description highlights a contradiction between scholarly discussion and media image. While scholars explore both negative and positive aspects of the role and practice of lobbying as it evolves, the media mainly emphasize the image of lobbying as a new occurrence where a group of professionals gain political power at the expense of democracy (Hall, 2015; Strömbäck, 2011).

In summary, it is evident that lobbying is a complicated matter, but this complexity is hardly captured in Swedish media coverage. Despite the changing role and practice in contemporary Sweden, lobbying is framed without nuance, which in many ways is unsuitable to explain the current Swedish lobbying industry. A clear contradiction is evident in the relation between the scholarly discussion on the concept and the media image of the practice. In future research, it would be interesting to explore whether and why certain media and journalists report on lobbying, that is, find it newsworthy, and why similar frames are reproduced. Moreover, a more qualitative approach may shed further light on the societal debate, and a dialog with lobbying professionals and political policy makers to understand their perception of the practice may give a more faceted understanding of lobbying in a Swedish context. How do lobbyists work? What are their 
incentives, channels, and strategies? What does this powershift entail? How will this influence Swedish democracy? And what does the different understanding of lobbying in the media and scholarly debate implicate? There are many dimensions of lobbying that need to be addressed further to understand the practice fully. These questions are important since the role and practice of lobbying has become increasingly influential in modern politics.

\section{Funding}

The author(s) received no financial support for the research, authorship, and/or publication of this article.

\section{References}

Badie B, Berg-Schlosser D and Morlino L (2010) International Encyclopedia of Political Science. Beverly Hills, CA: SAGE.

Baumgartner FR, Berry JM, Hojnacki M, et al. (2009) Lobbying and Policy Change: Who Wins, Who Loses, and Why. Chicago, IL: University of Chicago Press.

Bennett A and Elman C (2006) Qualitative research: Recent developments in case study methods. Annual Review of Political Science 9: 455-476.

Bennett WL and Entman RM (2001) Mediated Politics: Communication in the Future of Democracy. Cambridge: Cambridge University Press.

Boddewyn JJ (2012) Beyond 'The evolving discipline of public affairs'. Journal of Public Affairs 12: $98-104$.

Campos NF and Giovannoni F (2007) Lobbying, corruption and political influence. Public Choice 131: $1-21$.

Coombs WT and Holladay SJ (2013) It's Not Just PR: Public Relations in Society. Hoboken, NJ: John Wiley \& Sons.

Davidson S (2015) Everywhere and nowhere: Theorising and researching public affairs and lobbying within public relations scholarship. Public Relations Review 41: 615-627.

Davidson S and Rowe O (2016) Emerging from the shadows? Perceptions, problems and potential consensus on the functional and civic roles of public affairs practice. Public Relations Inquiry 5: 5-32.

De Vreese C (2014) Mediatization of news: The role of journalistic framing. In: Strömbäck J and Esser F (eds) Mediatization of Politics: Understanding the Transformation of Western Democracies. New York: Palgrave McMillan, pp. 137-155.

De Vreese CH (2005) News framing: Theory and typology. Information Design Journal+ Document Design 13: 51-62.

Dühring L (2015) Lost in translation? On the disciplinary status of public relations. Public Relations Inquiry 4: 5-23.

Edwards L (2012) Defining the 'object' of public relations research: A new starting point. Public Relations Inquiry 1: 7-30.

Eising R (2007) Institutional context, organizational resources and strategic choices explaining interest group access in the European Union. European Union Politics 8: 329-362.

Entman RM (2004) Projections of Power: Framing News, Public Opinion, and US Foreign Policy. Chicago, IL: University of Chicago Press.

Esser F and Strömbäck J (2014) Mediatization of Politics: Understanding the Transformation of Western Democracies. New York: Palgrave Macmillan.

Esser F, Strömbäck J and de Vreese CH (2012) Reviewing key concepts in research on political news journalism: Conceptualizations, operationalizations, and propositions for future research. Journalism 13: 139-143. 
Esteban J and Ray D (2006) Inequality, lobbying, and resource allocation. The American Economic Review 96: 257-279.

Falasca K and Nord L (2013) Structures, strategies and spin: Government communication. In: Sanders K and Canel MJ (eds) Government Communication: Cases and Challenges. New York: Bloomsbury, pp.27-44.

Fleisher C (2012) Anniversary retrospective, perspective and prospective of corporate public affairs: Moving from the 2000+ PA Model toward Public Affairs 2.0. Journal of Public Affairs 12: 4-11.

Garsten C, Rothstein B and Svallfors S (2015) Makt utan mandat: De policyprofessionella i svensk politik. Stockholm: Dialogos Förlag.

George AL and Bennett A (2005) Case Studies and Theory Development in the Social Sciences. Cambridge, MA: The MIT Press.

Hall P (2015) The Swedish administrative model. In: Pierre J (ed.) The Oxford Handbook of Swedish Politics. New York: Oxford University Press, pp.299-314.

Hill M and Varone F (2014) The Public Policy Process. New York: Routledge.

Ihlen $\varnothing$ and Berntzen Ø (2007) When lobbying backfires: Balancing lobby efforts with insights from stakeholder theory. Journal of Communication Management 11: 235-246.

Ihlen $\varnothing$ and Van Ruler B (2009) Introduction: Applying Social Theory to Public Relations. New York: Routledge.

Kaufmann D and Vicente PC (2011) Legal corruption. Economics \& Politics 23: 195-219.

Larsson L (2006) Public relations and democracy: A Swedish perspective. In: L'Etang J and Pieczka M (eds) Public Relations Critical Debates and Contemporary Practice. Mahwah, NJ: Lawrence Erlbaum Associates, pp.123-142.

Larsson L (2007) Public trust in the PR industry and its actors. Journal of Communication Management 11: 222-234.

Larsson L (2009) Stadig misstro mot lobbyismen. In: Weibull L and Holmberg S (eds) Svensk höst. SOM-undersökningen 2008. Göteborg: Göteborgs Universitet, pp.155-163.

Lowery D (2007) Why do organized interests lobby? A multi-goal, multi-context theory of lobbying. Polity 39: 29-54.

Mahoney C (2008) Brussels versus the Beltway: Advocacy in the United States and the European Union. Washington, DC: Georgetown University Press.

Milbrath LW (1963) The Washington Lobbyists. Chicago, IL: Rand McNally.

Moloney K (2002) Rethinking Public Relations: The Spin and the Substance. London: Routledge.

Naurin D (2007a) Backstage behavior? Lobbyists in public and private settings in Sweden and the European Union. Comparative Politics 39: 209-228.

Naurin D (2007b) Deliberation behind Closed Doors: Transparency and Lobbying in the European Union. Colchester: ECPR Press.

Nothhaft C (2011) Transparent lobbying? En studie av politisk påverkan i Europaparlamentet. In: Falkheimer J and Heide M (eds) Strategisk kommunikation - Forskning och praktik. Lund: Studentlitteratur AB, pp.91-110.

Nownes AJ (2006) Total Lobbying: What Lobbyists Want (And How They Try to Get It). Cambridge: Cambridge University Press.

Nownes AJ and DeAlejandro KW (2009) Lobbying in the new millennium: Evidence of continuity and change in three states. State Politics \& Policy Quarterly 9: 429-455.

Petersson O (2015) Rational politics: Commissions of inquiry and the referral system in Sweden. In: Pierre J (ed.) The Oxford Handbook of Swedish Politics. New York: Oxford University Press, pp.650-662.

Reinemann C, Stanyer J,Scherr S, et al. (2012) Hard and soft news: A review of concepts, operationalizations and key findings. Journalism 13: 221-239. 
Riff D, Lacy S and Fico F (2014) Analyzing Media Messages: Using Quantitative Content Analysis in Research. New York: Routledge.

Scheufele DA and Tewksbury D (2007) Framing, agenda setting, and priming: The evolution of three media effects models. Journal of Communication 57: 9-20.

Schwarzmantel JJ (1994) The State in Contemporary Society: An Introduction. Hemel Hempstead: Harvester.

Shah DV, McLeod DM, Gotleib MR, et al. (2009) Framing and agenda setting. In: Nabi RL and Oliver MB (eds) The Sage Handbook of Media Processes and Effects. Thousand Oaks, CA: SAGE, pp.83-98.

Somerville I (2011) Managing public affairs and lobbying: Persuasive communication in the policy sphere. In: Moss D and DeSanto B (eds) Public Relations: A Managerial Perspective. London: SAGE, pp.167-192.

Strömbäck J (2011) Lobbyismens problem och möjligheter: Perspektiv från dem som både lobbar och har blivit lobbade. Stockholm: Precis.

Strömbäck J and Nord L (2008) Media and politics in Sweden. In: Strömbäck J, Orsten M and Aalberg T (eds) Communicating Politics: Political Communication in the Nordic Countries. Gothenburg: Nordicom, pp.103-121.

Svallfors S (2016a) Out of the golden cage: PR and the career opportunities of policy professionals. Politics \& Policy 44: 56-73.

Svallfors S. (2016b) Politics as organised combat - New players and new rules of the game in Sweden. New Political Economy 21: 505-519.

Tallberg J, Beach D, Naurin D, et al. (2011) Makten I Europa: Demokratirådets rapport 2011. Stockholm: SNS Förlag.

\section{Author biographies}

Elin Helgesson is a PhD student in Media and Communication Science, DEMICOM Centre for Study of Democracy and Communication at Mid Sweden University, Sweden. Her dissertation deals in general with strategic political communication and some parts specifically focus on public affairs and lobbying in a Swedish context.

Kajsa Falasca is an assistant professor in Media and Communication science, DEMICOM Centre for Study of Democracy and Communication at Mid Sweden University, Sweden. Her research covers areas such as strategic political communication, professionalization of political communication, public opinion, as well as the mediatization of politics and news. 